\title{
Influence of water volume reduction on the phytoplankton dynamics in a semi- arid man-made lake: A comparison of two morphofunctional approaches
}

\author{
GUSTAVO G. BRAGA \& VANESSA BECKER
}

\begin{abstract}
Significant reductions in the water levels of lakes are influenced by droughts and freshwater demands, especially in semi-arid regions, where hydric stress is greater. The aim of this study was to investigate the dynamics of phytoplankton during two different water volume periods resulting from an extended drought in a semi-arid lake. Another objective was to compare two functional approaches to test which one of these best captures phytoplankton variability as a function of environmental variability. Multivariate analyses performed using the Reynolds Functional Groups (RFG) and Morphology-Based Functional Groups (MBFG) classification schemes indicated two periods, high and a low water volume. The results demonstrated the importance of light availability on phytoplankton assemblages as these two periods showed significant differences in water transparency and phytoplankton composition. During extended droughts the reduction in water volume enhances the development of bloom-forming cyanobacteria through the limitation of light in a eutrophic man-made lake. Moreover, both functional traits approaches demonstrated the effect of light availability on phytoplankton assemblage composition and can be applied in similar systems. However, the RFG classification provides more information and allows a more detailed description of the algal assemblages.
\end{abstract}

Key words: hydric deficit, cyanobacteria, eutrophication, Reynolds Functional Groups, Morphology-Based Functional Groups.

\section{INTRODUCTION}

Physical and chemical changes in water columns associated with climatic circumstances largely determine changes in the composition of phytoplankton assemblages in lakes and reservoirs (Tundisi 1990). In ecosystems with large variations in water levels, the annual and inter-annual variability of phytoplankton abundance and composition can be strongly influenced by peculiar hydrological regimes (Harris \& Baxter 1996) and also by changes in mixing regimes (Naselli-Flores \& Barone 2005). A number of studies demonstrate that water level fluctuations can affect the abundance, biomass, composition, and diversity of pelagic primary producers through changes in light availability and nutrients (Kangur et al. 2003, Naselli-Flores \& Barone 2005, Leira \& Cantonati 2008, Costa et al. 2016).

Reservoirs and man-made lakes in semiarid regions are mostly shallow and subjected to wide seasonal water volume variations as a result of the precipitation irregularity in these regions (Coops et al. 2003, Bucak et al. 2012, Terefi et al. 2014, Figueiredo \& Becker 2018). A considerable number of these reservoirs can dry out completely during intense droughts, which 
results in agricultural losses and socioeconomic problems, as water supply collapse. Therefore, considerable attention should be given to managing these water resources.

Phytoplankton plays an important role in aquatic ecosystems, and they are sensitive to water level fluctuations, as well as changes in the availability of light and nutrients (Reynolds 2006). Because of the brief generation and replication times of these organisms (hours to days), phytoplankton can respond quickly to environmental changes (Reynolds 1990). Thus, they can be considered good indicators of natural or artificial changes in aquatic systems (Reynolds 1990).

During drought events, the water volume reductions and high water residence times of lakes and reservoirs contribute to increased phytoplankton biomass, favoring the development of species adapted to low light and high nutrient availability such as some of the cyanobacteria species (Naselli-Flores 2000, 2003, Bouvy et al. 2003, Geraldes \& Boavida 2005, Jeppesen et al. 2015).

A useful way of studying changes in phytoplankton assemblages is to group organisms based on similarities in their adaptive strategies (Litchman \& Klausmeier 2008). Thus organisms can be grouped according to the morpho-physiological traits that respond to light availability and nutrient concentration in a similar way. This approach was named the trait-based approach, and it facilitates an understanding of the species selection dynamics in the community because it captures greater variability than do taxonomic approaches (Kruk et al. 2002, Hu et al. 2013).

The functional trait-based classification proposed by Reynolds et al. (2002) and reviewed by Padisák et al. (2009) categorizes phytoplankton populations into functional groups. These groups are often polyphyletic and are based on attributes and physiological, morphological, and ecological similarities of the species that can potentially dominate or codominate certain habitats (Reynolds et al. 2002). This approach, called the Reynolds Functional Groups (RFG) classification scheme (Kruk et al. 2017), is widely used in ecological studies of freshwater phytoplankton and is applicable to different types of environments around the globe (Padisák et al. 2006, 2009, Becker et al. 2009, Barbosa et al. 2011, Crossetti et al. 2013, Costa et al. 2016, Souza et al. 2016, Jati et al. 2017, Silva et al. 2018, Selmeczy et al. 2019).

Another functional classification was proposed by Kruk et al. (2010), in which organisms are classified into only seven groups based on measurable morphological criteria (Morphology-Based Functional Groups [MBFG]). However, in a recent study the inclusion of an additional MBFG (group VIII) was proposed that includes nitrogen-fixing cyanobacteria (Reynolds et al. 2014). Some studies demonstrated greater ease and predictability of the MFBG scheme compared with other functional classifications because MFBG classifications are based purely on simple morphological traits (Kruk et al. 2011, Hu et al. 2013, Rangel et al. 2016).

Based on studies of hydrological regime effects on water quality and the functional approaches of phytoplankton communities, the hypothesis of this work was that the water level reduction caused by drought favors the development of bloom-forming functional groups that comprise filamentous and colonial organisms adapted to a stable, warmer, and turbid environment.

The aim of this study was to investigate phytoplankton dynamics during two different water volume periods resulting from an extended drought in a semi-arid lake. We also compared two functional approaches to test which one of 
these best captures phytoplankton variability as a function of environmental variability.

\section{MATERIALS AND METHODS}

\section{Study area}

Dourado man-made lake (06 $14^{\prime} 48^{\prime \prime}$ S: $36^{\circ} 30^{\prime} 30^{\prime \prime}$ W) located in Currais Novos, a city in a semi-arid region in northeastern Brazil (Fig. 1). The regional climate is tropical semi-arid and of type BSW'h according to the Köppen climate classification (Alvares et al. 2014). The average temperature exceeds $25{ }^{\circ} \mathrm{C}$, and there is a pronounced temporal and spatial variation of annual rainfall (300-1000 mm.year ${ }^{-1}$ ). This shallow tropical lake was built in 1982 from the impoundment of the São Bento River for multiple uses, including water supply, irrigation, fishing, and recreation. Dourado's water capacity is approximately $10,300,000 \mathrm{~m}^{3}$, with a surface area of $3.16 \mathrm{~km}^{2}$ and a maximum depth of $10 \mathrm{~m}$.

\section{Sampling}

Water samples were taken at monthly intervals from May 2011 to April 2013 at a sampling station near the dam (Figure 1). Vertical profiles for temperature, pH, dissolved oxygen (DO), and conductivity were measured in situ using a multi-sensor probe (Hydrolab DS5) at 1-m intervals from the surface to the bottom. Water transparency was estimated according to Secchi disk depth. Integrated samples (between 0.5 and $3 \mathrm{~m}$ depth) for nutrients and phytoplankton analyses were collected with a Van Dorn bottle $(2 \mathrm{~L})$. Phytoplankton samples were fixed with acetic Lugol's solution for later identification and counting.

\section{Sample analysis}

Total phosphorus (TP) was measured using a spectrophotometric method (Valderrama 1981). Soluble reactive phosphorus (SRP) and nitrate was measured in water filtered on $0.45-\mu \mathrm{m}$ glass-fiber filters (Murphy \& Riley 1962). Total and fixed suspended solids (inorganic solids) were determined by gravimetry after drying the filters overnight at $100{ }^{\circ} \mathrm{C}$ and ignition of filters at $500{ }^{\circ} \mathrm{C}$ for $3 \mathrm{~h}$ (APHA 2012). The organic suspended solids (OSS) were measured by the difference between total suspended solids and inorganic suspended solids (APHA 2012). Chlorophyll was measured by spectroscopy

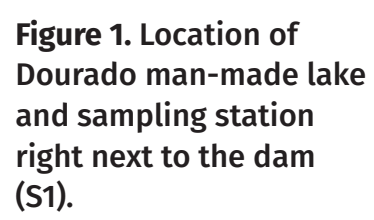

Figure 1. Location of Dourado man-made lake and sampling station (S1).

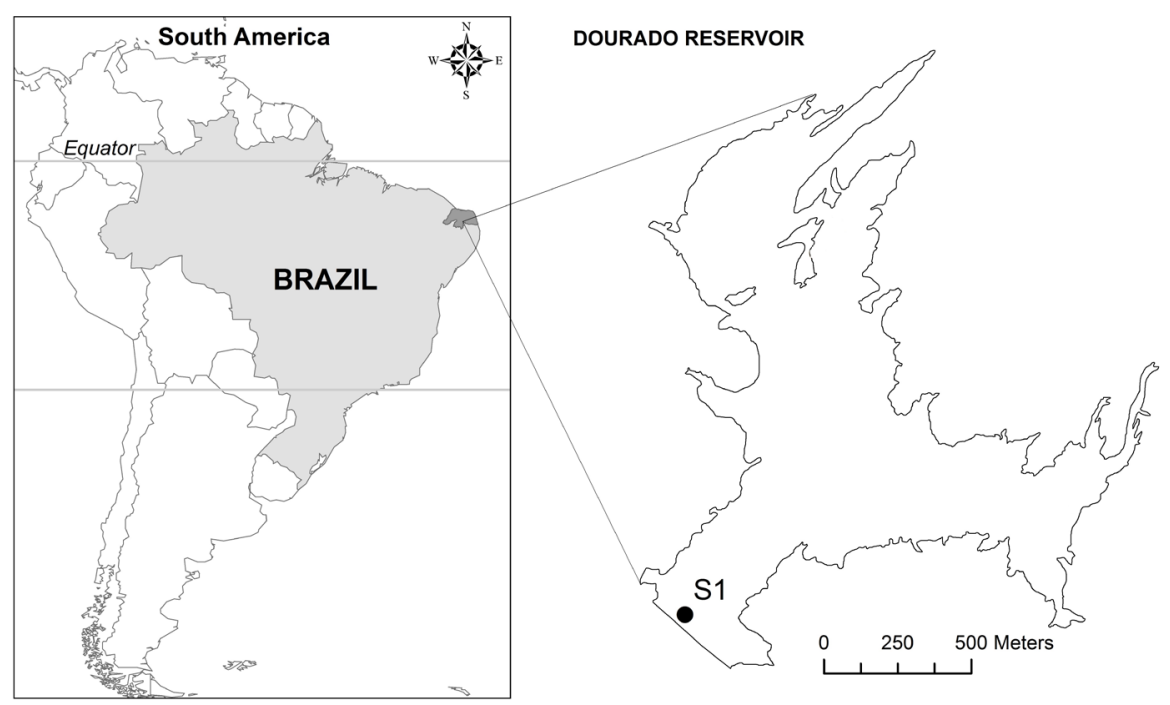


using the Jespersen and Christoffersen (1988) methodology.

The identification and counting of phytoplankton were performed using a standard optical microscope (1000x) and an inverted microscope (400x). Individuals (cells, colonies, filaments) were counted in random fields (Uhelinger 1964) using a sedimentation technique (Utermöhl 1958), and at least 100 specimens of the most abundant species were counted (Lund et al. 1958).

\section{Data analysis}

Monthly precipitation data and historical averages for the past 30 years were provided by the State Agricultural Research Company of Rio Grande do Norte (Empresa de Pesquisa Agropecuária do RN [EMPARN]). A standardized precipitation index at a timescale of 12 months (SPI12), which is proper for detecting hydrological drought events, was used to categorize the intensity of the precipitation (Mckee et al. 1995, Guttman 1999, Mishra \& Singh 2010). The Standardized Precipitation Index (SPI) for any location is calculated based on the long-term precipitation record for a desired period (Jain et al. 2015). The SPI is perhaps the most widely used drought index (Mishra \& Singh 2010). McKee et al. (1995) developed the SPI to identify and monitor drought events using monthly rainfall data. It is intended to identify drought periods, as well as the severity of droughts at multiple time steps, such as at 1, 3, 6, 9, 12, or 24 months (Jain et al. 2015).

Monthly average values of SPI accumulation at 12 months (SPI12) were obtained from the online database of the National Institute of Meteorology (Instituto Nacional de Meteorologia [INMET]). Water volume values were provided by the State Environmental Water Resources Agency of Rio Grande do Norte (Secretaria do
Meio Ambiente e dos Recursos Hídricos do Rio Grande do Norte [SEMARH]).

The criteria used to determine trophic states were those identified by Thornton \& Rast (1993).

The study period was divided into two periods: the high volume period, when the water volume was higher than $50 \%$ of the total capacity of the reservoir, and the low volume period, when the water volume was lower than $50 \%$. This classification was supported as a result of a two-way cluster analysis performed with PC-ORD ${ }^{\circledR}$ software using water volume and limnological variables, which showed the same pattern in sample characterizations.

Euphotic zone depth $\left(z_{\text {eu }}\right)$ was estimated by multiplying the Secchi depth by 2.7 (Cole 1994). The temperature profile was used to determine mixing and stratification of the water column using a minimum difference of $0.5{ }^{\circ} \mathrm{C}$ for the thermal gradient (Dantas et al. 2012). The euphotic zone depth and maximum depth ratio $\left(z_{\text {eu }} / z_{\max }\right)$ were used to assess the availability of light (Jensen et al. 1994).

Biovolume $\left(\mathrm{mm}^{3} \mathrm{~L}^{-1}\right)$ was calculated from the approximate geometric shapes (Hillebrand et al. 1999), assuming the unit fresh weight expressed as mass of $1 \mathrm{~mm}^{3} \mathrm{~L}^{-1}=1 \mathrm{mg} \mathrm{L}^{-1}$ (Wetzel \& Likens 2000). The descriptor species were defined as those that contributed more than $5 \%$ of the total biomass and were classified using two different functional trait approaches: RFG (Reynolds et al. 2002, Padisák et al. 2009, Kruk et al. 2017) and MBFG (Kruk et al. 2010, Reynolds et al. 2014). Species diversity $\left(H^{\prime}\right)$ was estimated using the Shannon-Wiener index (Shannon \& Weaver 1963) based on biomass and expressed in bits per milligram, as recommended by Sommer et al. (1993).

Descriptive statistics and exploratory analysis were performed using Statistica ${ }^{\circledR}$ software. A one-way analysis of variance (ANOVA) between higher and lower volume 
samples and $z_{\text {eu }} z_{\max }$ was also performed to verify significant differences between the light availability in both periods. A two-way cluster analysis was performed to assess similarities between samples, as well as to verify temporal patterns in variables.

For a description of the relationships between the dominant groups of phytoplankton and the environmental variables investigated, a redundancy analysis (RDA) was performed for each functional approach. The data on the groups' abundance were previously analyzed by correspondence analysis and are not biased by detrended correspondence analysis (DCA), indicating that a linear ordering model would be more appropriate. These ordinations were performed using PC-ORD version 6.0 software (McCune \& Mefford 2011). The significance of the variables was analyzed using the Monte Carlo permutation test.

\section{RESULTS}

\section{Meteorological and hydrological scenarios}

Two distinct hydrological events occurred in this study. The first one was a heavy rainy season at the beginning of the study with precipitation above the historical average (May 2011 - July 2011) followed by normal hydrological conditions (Fig. 2). The second event was a prolonged drought scenario that started with moderate dry conditions in April 2012 and reached extremely dry conditions status from January to March 2013 (Fig. 2).

Because of the lack of rainfall, evaporation rates and water consumption, a reduction of nearly $90 \%$ of the water volume was observed (Fig. 3). The study was therefore divided into two distinct periods defined by water level fluctuation: (I) high water volume period, marked by water volumes above $50 \%$ of the total capacity and also by moderately wet and normal hydrological conditions (from May 2011 to January 2012); and (II) low water volume period, characterized by water volumes lower than $50 \%$ of the total capacity and hydrological conditions varying from normal to extremely dry (from February 2012 to April 2013) (Figs. 2 and 3).

\section{Limnological scenario}

The water column was mixed for most of the study period, and no anoxic conditions were detected. Water level reduction manifested both in maximum depth $\left(z_{\max }\right)$ and in euphotic
Figure 2. Monthly rainfall, rainfall historical average and standardized precipitation index (SPI 12) from May 2011 to April 2013 for Currais Novos City.

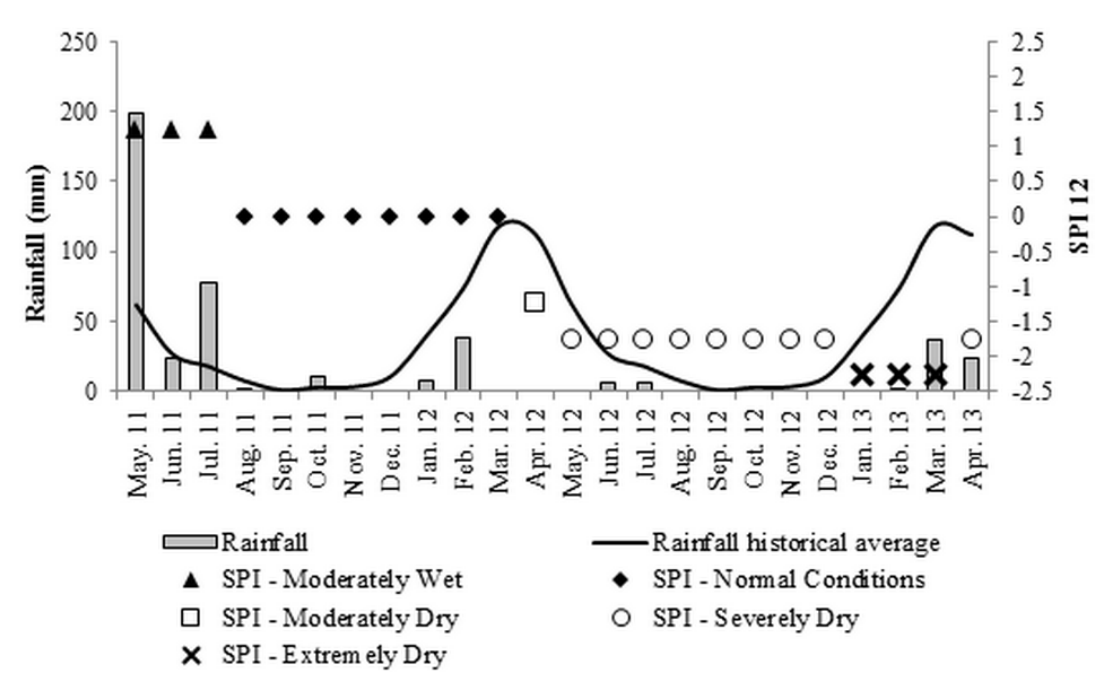

An Acad Bras Cienc (2020) 92(1) e20181102 5 5 17 
depth $\left(z_{\text {eu }}\right)$ (Table I). Light availability was higher during higher volume period and was reduced in lower volume period. The difference in light availability between the periods was significant $\left(F=47.48 ; R^{2}=0.87 ; P<0.0001\right)$. The low light availability in Lake Dourado during the low volume period was associated with the presence of OSS which indicates turbidity caused by high phytoplankton biomass (Table I).

In general, the lake could be classified as eutrophic based on total phosphorus and chlorophyll-a concentrations. There was an increase in these two variables during lowvolume periods, indicating more eutrophic conditions compared with high volume periods (Table I, Fig. 3).
The two-way cluster analysis demonstrates the similarity between environmental variables and monthly samplings (Fig. 4). There are two main clusters with different patterns in water volume, transparency, nutrients, and chlorophyll concentrations. These differences were also considered for distinguishing high volume from low-volume periods. The first cluster is the period from May 2011 to January 2012, characterized by water volumes above $50 \%$ of the total capacity of the reservoir and higher transparency $\left(z_{e u}\right)$; thus this cluster was named the high water volume period (Fig. 4). The second cluster is composed of samples (February 2012 to April 2013) corresponding to the low water volume period (below 50\%), associated with high $\mathrm{pH}$, conductivity, and chlorophyll-a (Fig. 4).

Table I. Descriptive statistics (average, minimum and maximum) of the limnological variables studied at Dourado man-made lake during periods identified by water volume.

\begin{tabular}{|c|c|c|}
\hline Variables & High Water Volume & Low Water Volume \\
\hline Temperature $\left({ }^{\circ} \mathrm{C}\right)$ & $26.4(24.6-28.3)$ & $26.7(24.3-30.2)$ \\
\hline $\mathrm{pH}$ & $7.53(6.50-8.51)$ & $8.44(7.78-9.40)$ \\
\hline$z_{\max }(m)$ & $9.0(8.1-9.7)$ & $5.6(2.1-8.2)$ \\
\hline$z_{\text {eu }}(m)$ & $2.9(2.2-4.0)$ & $0.8(0.3-1.6)$ \\
\hline $\mathrm{z}_{\text {eu }} / \mathrm{z}_{\max }$ & $0.32(0.24-0.42)$ & $0.15(0.06-0.23)$ \\
\hline Conductivity $\left(\mu \mathrm{S} \mathrm{cm}^{-1}\right)$ & $801.9(635.0-936.0)$ & $1548.0(945.0-2653.0)$ \\
\hline $\mathrm{DO}\left(\mathrm{mg} \mathrm{L^{-1 }}\right)$ & $7.11(6.17-7.89)$ & $7.89(5.71-9.65)$ \\
\hline $\mathrm{ISS}\left(\mathrm{mg} \mathrm{L}^{-1}\right)$ & $2.05(0.40-4.00)$ & $7.45(0.00-20.76)$ \\
\hline OSS (mg L-1) & $6.43(0.00-27.60)$ & $20.37(4.80-40.80)$ \\
\hline $\operatorname{TP}\left(\mu g L^{-1}\right)$ & $70.70(26.00-149.57)$ & $145.24(38.20-445.00)$ \\
\hline $\operatorname{SRP}\left(\mu g L^{-1}\right)$ & $40.58(0.50-131.00)$ & $9.14(1.16-28.57)$ \\
\hline $\operatorname{DIN}\left(\mu g L^{-1}\right)$ & $659.02(528.84-803.15)$ & $1453.29(503.51-3206.19)$ \\
\hline Chl-a $\left(\mu g L^{-1}\right)$ & $15.12(5.66-27.82)$ & $142.37(42.68-332.85)$ \\
\hline Phytoplankton biomass (mg L ${ }^{-1}$ ) & $11.29(5.60-22.14)$ & $63.79(15.20-107.17)$ \\
\hline Phytoplankton diversity (bits $\mathrm{mg}^{-1}$ ) & $2.01(1.42-2.55)$ & $1.30(0.73-1.94)$ \\
\hline
\end{tabular}

$z_{\max }=$ maximum depth; $z_{e u}=$ euphotic zone; DO = Dissolved Oxygen; ISS = Inorganic Suspended Solids; OSS = Organic Suspended Solids; TP = Total Phosphorus; SRP = Soluble Reactive Phosphorus; DIN = Dissolved Inorganic Nitrogen; Chl-a = Chlorophyll- $a$. 


\section{Phytoplankton dynamics}

Total phytoplankton biomass variation showed an increasing pattern, reaching maximum values during the low volume period. Shannon-Wiener diversity was higher during high volume periods while the phytoplankton community was less diverse in low-volume periods (Table I).

A total of 54 taxa were identified during the study, but only 27 were considered descriptor taxa and were distributed among $10 \operatorname{RFGs}\left(\mathbf{S}_{\mathbf{N}^{\prime}}\right.$ $\mathbf{M}, \mathbf{H}_{\mathbf{1}}, \mathbf{S}_{\mathbf{1}}, \mathbf{X}_{\mathbf{1}}, \mathbf{K}, \mathbf{L}_{\mathbf{0}}, \mathbf{J}, \mathbf{F}$, and $\mathbf{P}$ ) and among six (06) morphology-based functional groups - MBFG (I, III, IV, VI, VII, and VIII) (Table II).

Using the RFG approach, groups $\mathbf{F}$ and $\mathbf{J}$ were predominant, including mostly green algae with a high affinity for light and nutrients. This presented a significant contribution to phytoplankton biomass during the high volume period. Group $\mathbf{P}$, which includes diatoms and some green algae, also contributed to the biomass in the period. The functional groups $\mathbf{S}_{\mathbf{N}}$ and $\mathbf{M}$, which both include cyanobacteria, represented the majority contribution to phytoplankton biomass during the low-volume periods, followed by $\mathbf{S}_{\mathbf{1}}$ and $\mathbf{H}_{\mathbf{1}}$ (Fig. 5a).

The MBFG approach presented groups IV (organisms of medium size lacking specialized traits) and VI (non-flagellated organisms with siliceous exoskeletons) as the most important contributors of phytoplankton biomass during the high volume periods and groups VIII (filamentous nitrogen-fixing cyanobacteria) and VII (large mucilaginous colonies) as those that most contributed to biomass during the low volume periods (Fig. 5b). It is important to mention that groups VIII and VII were present during high volume periods, although they were less abundant than in the low volume period.

According to the redundancy analysis based on the RFG (Fig. 6a), the first two axes accounted for $63.4 \%$ of the variance (axis 1: $54.5 \%$; axis 2: $8.8 \%)$. The Monte Carlo test indicated a significant correlation between environmental variables and the first axis $(P=0.001)$. The first axis was mainly correlated with $z_{\text {eu }}(0.93)$, water volume (0.82), and conductivity (-0.79), while TP $(-0.47)$ and SRP (0.42) were correlated to axis 2. Figure 7a shows the biplots (first two axes) of monthly samples and functional groups (FGs) with respect to the environmental variables.

The results of the RDA carried out on the MBFG (Fig. 6b) accounted for $63.9 \%$ of explained variance (axis 1: 58.3\%; axis 2: 5.6\%), a similar percentage to the RFG approach. The Monte Carlo test was also significant for the first axis $(P=0.001)$. The first axis was also correlated with $\mathrm{Z}_{\text {eu }}(0.95)$, water volume (0.83), and conductivity
Figure 3. Monthly values of maximum volume capacity and chlorophyll-a concentrations on Dourado during the study period. The dark dot indicates when (February 2012) the water volume reached least half of the maximum capacity ( $<50 \%)$.

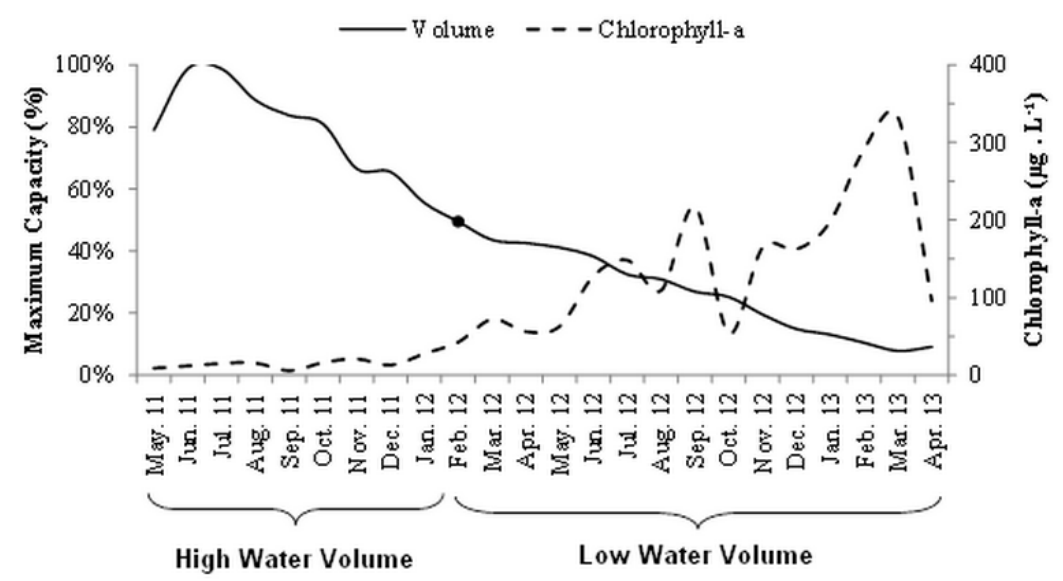

An Acad Bras Cienc (2020) 92(1) e20181102 7| 17 
Table II. List of dominant taxa founded in Dourado reservoir and their Reynolds' Functional Groups (RFG) and Morphology-Based Functional Groups (MBFG) classification.

\begin{tabular}{|c|c|c|c|}
\hline Species & RFG & MBFG & Phylum \\
\hline Aphanizomenon gracile (Lemmermann) Lemmermann & $\mathrm{H} 1$ & VIII & Cyanobacteria \\
\hline Aphanocapsa elachista West \& G.S. West & K & VII & Cyanobacteria \\
\hline Aphanothece sp. & K & VII & Cyanobacteria \\
\hline Aulacoseira granulata (Ehrenberg) Simonsen & $\mathrm{P}$ & $\mathrm{VI}$ & Bacillariophyta \\
\hline Botryococcus sp. & $\mathrm{F}$ & VII & Chlorophyta \\
\hline Chlorella vulgaris Beyerinck & $\mathrm{X} 1$ & IV & Chlorophyta \\
\hline Chroococcus minor (Kützing) Nägeli & $\mathrm{L}_{0}$ & । & Cyanobacteria \\
\hline Coelastrum astroideumDe Notaris & J & IV & Chlorophyta \\
\hline Cronbergia sp. & $\mathrm{H} 1$ & VIII & Cyanobacteria \\
\hline Crucigenia sp. & J & IV & Chlorophyta \\
\hline Cuspidothrix sp. & $\mathrm{H} 1$ & VIII & Cyanobacteria \\
\hline Cyanodictyon imperfectum Cronberg \& Weibull & K & VII & Cyanobacteria \\
\hline Cylindrospermopsis raciborskii (Woloszynska) Seenayya \& Subba Raju & $\mathrm{S}_{\mathrm{N}}$ & VIII & Cyanobacteria \\
\hline Dolichospermum sp. & $\mathrm{H} 1$ & VIII & Cyanobacteria \\
\hline Geitlerinema amphibium (C. Agardhex Gomont) Anagnostidis & S1 & III & Cyanobacteria \\
\hline Melosira sp. & $P$ & $\mathrm{VI}$ & Bacillariophyta \\
\hline Microcystis sp. & M & VII & Cyanobacteria \\
\hline Monoraphidium minutum (Nägeli) Komárková-Legnerová & $\mathrm{X} 1$ & IV & Chlorophyta \\
\hline Nephrocytium sp. & $\mathrm{F}$ & IV & Chlorophyta \\
\hline Oocystis sp. & $\mathrm{F}$ & VII & Chlorophyta \\
\hline Planktolyngbya limnetica (Lemmermann) Komárková-Legnerová \& Cronberg & S1 & IV & Cyanobacteria \\
\hline Planktothrix isothrix (Skuja) Komárek \& Komárková & S1 & III & Cyanobacteria \\
\hline Scenedesmus acuminatus (Lagerheim) Chodat & J & IV & Chlorophyta \\
\hline Sphaerocavum brasiliense M.T de P. Azevedo \& C. L. Sant'Anna & M & VII & Cyanobacteria \\
\hline Staurastrum volans West \& G.S. West & $\mathrm{P}$ & IV & Charophyta \\
\hline Synechocystis aquatilis Sauvageau & $\mathrm{L}_{0}$ & । & Cyanobacteria \\
\hline Synechocystis cf. salina Wislouch & K & । & Cyanobacteria \\
\hline
\end{tabular}

(-0.81). Environmental variables presented low correlation indices in axis 2.

The results of these analyses indicated that the biomass of phytoplankton groups using both approaches can be predicted from the environmental variables. In both ordinations, low volume period samples were plotted separately from the high volume period samples. Thus there was a temporal tendency (pattern) from the positive side of axis 1 to the negative side of the same axis (Figs. $6 a$ and 6b).

The different optical conditions between periods expressed by $z_{\text {eu }}$ seem to be the most important variable determining the algal groups. 


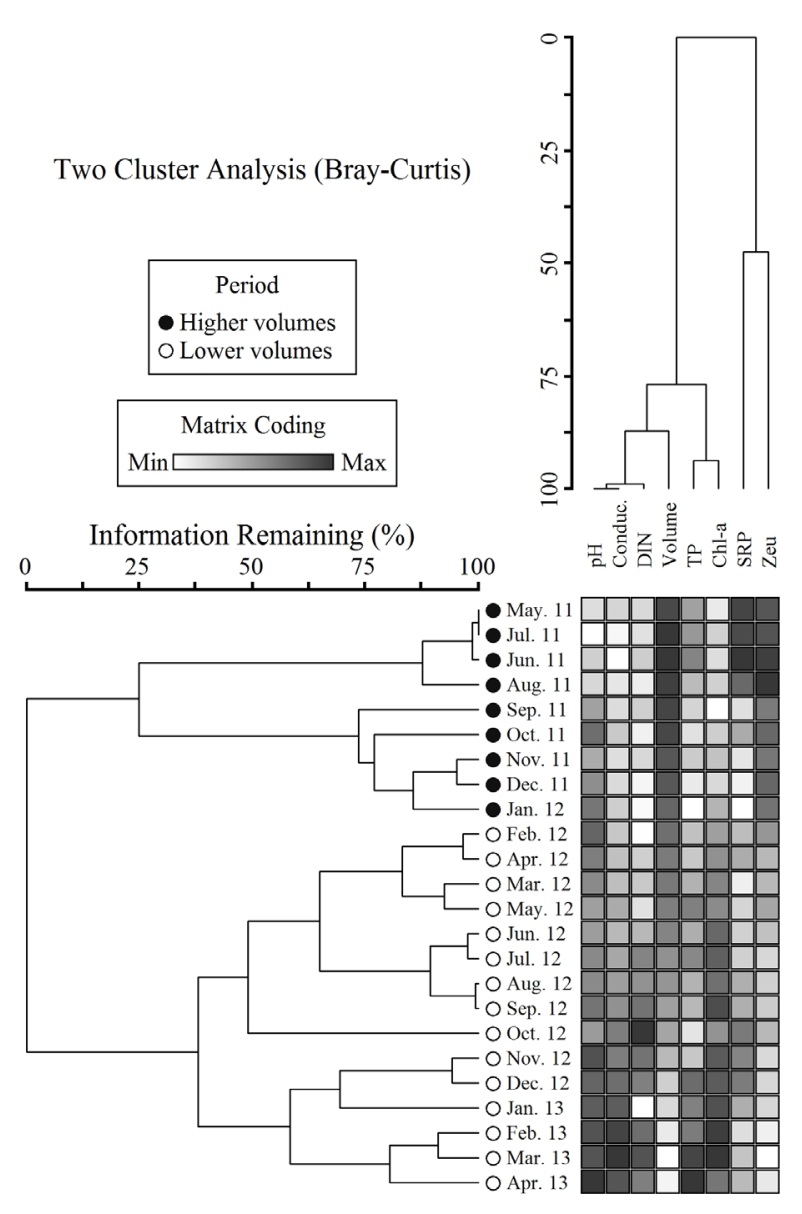

Figure 4. Two-way cluster analysis diagram of physicalchemical variables and monthly sampling. On the matrix, dark squares represent maximum values while white ones represent minimum values for each parameter (columns) during monthly samples (lines). Chl $-a=$ Chlorophyll-a; Conduc. $=$ Conductivity; $S R P=$ Soluble Reactive Phosphorus; TP = Total Phosphorus; $D I N=$ Dissolved Inorganic Nitrogen; $p H=$ Potential of Hydrogen; $z_{e u}=$ Euphotic depth; Volume = Water volume.

As an example, the RFGs $\mathbf{J}, \mathbf{P}$, and $\mathbf{F}$ and the MBFGs IV and $\mathbf{V I}$ seem to be associated with less turbid environments. On the other hand, groups $\mathbf{S}_{\mathbf{N}}$ and $\mathbf{S}_{\mathbf{1}}$ and MBFGs VIII and III presented higher abundance in less light availability.

\section{DISCUSSION}

Seasonal reduction in the water volume of a reservoir related to drought periods is considered an important environmental condition, especially for phytoplankton dynamics. In this respect, light availability and nutrient concentration in water columns are considered growth-limiting resources in determining phytoplankton assemblages (Reynolds 2006).

As a consequence of water level reductions in Lake Dourado, there was a tendency toward nutrient and phytoplankton biomass concentration that can be observed in TP, dissolved inorganic nitrogen (DIN), conductivity, and chlorophyll-a. As a result of phytoplankton biomass, the organic turbidity, which is indicated by OSS, increased during the low water volume period. Similar patterns in environmental conditions during drought events were reported by other studies in the same semi-arid region (Bouvy et al. 1999, 2003, Medeiros et al. 2015). The wind action may have favored mixing and prevented stratification, probably acting as a stabilizing factor of the turbid state in this shallow reservoir (Torremorell et al. 2007). Considering that cyanobacteria are a heterogeneous group in which each taxon has different ecophysiological adaptations, it is possible to associate their morphological traits with a prevailing environmental situation (Litchman et al. 2010, Mantzouki et al. 2016). Once the environmental conditions became more turbid and eutrophic, some cyanobacteria, such as Cylindrospermopsis and Planktothrix, were favored because they tolerate low light availability (Smith 1996, Mantzouki et al. 2016). Studies semi-arid regions (Huszar et al. 2000, Bouvy et al. 2000, Arfi 2003, Naselli-Flores 2003, Dantas et al. 2011, Medeiros et al. 2015, Brasil et al. 2016) demonstrate that water level reduction is associated with turbid conditions (organic turbidity) and greater 


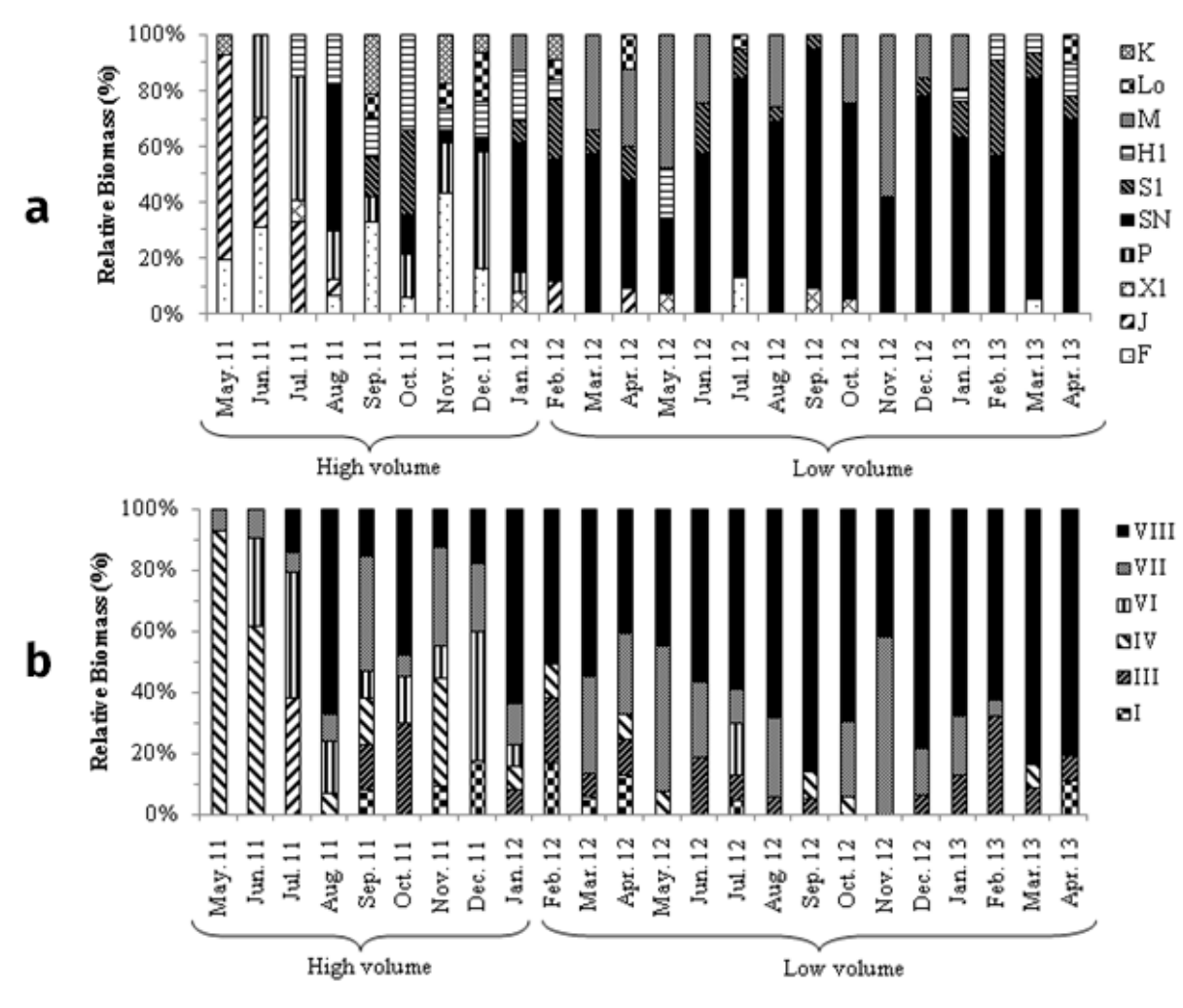

Figure 5. Relative biomass variation of Reynolds' Functional Groups (a) and Morphology-Based Funcional Groups (b) along the study. phytoplankton biomass is associated with cyanobacteria predominance, explaining why phytoplankton diversity is reduced during the lower volume period. To illustrate this, a recent study of four Chinese reservoirs showed that a decline in water levels boosts cyanobacteria dominance (Cylindrospermopsis, Microcystis, and Raphidiopsis) through the reduction of euphotic depth, demonstrating the tolerance of these organisms to turbid environments (Yang et al. 2016).

Light availability is one of the most important limnological key factors, and it exerts profound effects on phytoplankton diversity (Reynolds 1998) and competition (Reynolds 2006). Lightlimiting conditions prevail in reservoirs in Brazilian semi-arid regions (Barbosa et al. 2012), and previous studies have shown that there is a tendency in more turbid conditions toward greater phytoplankton biomass and cyanobacteria blooms during drought periods
(Huszar et al. 2000, Bouvy et al. 2003, Soares et al. 2013, Brasil et al. 2016).

Considering that water level fluctuation is an important driver in aquatic ecosystems, as proposed by Scheffer \& Jeppesen (2007), it is possible to compare the high volume period to a clear-water state and the low volume period to a turbid state. These two states shift in the function of water level fluctuations caused by the duration of droughts and wet periods.

Our results demonstrate that the biomass of phytoplankton groups in both approaches used in this study can be predicted from the environmental variables. The analyses show the separation between the high water-volume period, marked by higher transparency values, and the low water volume period, when turbid conditions prevailed. The difference between the percentages of the explained variance of the two approaches was not considerable, indicating that both are similar in this study. 


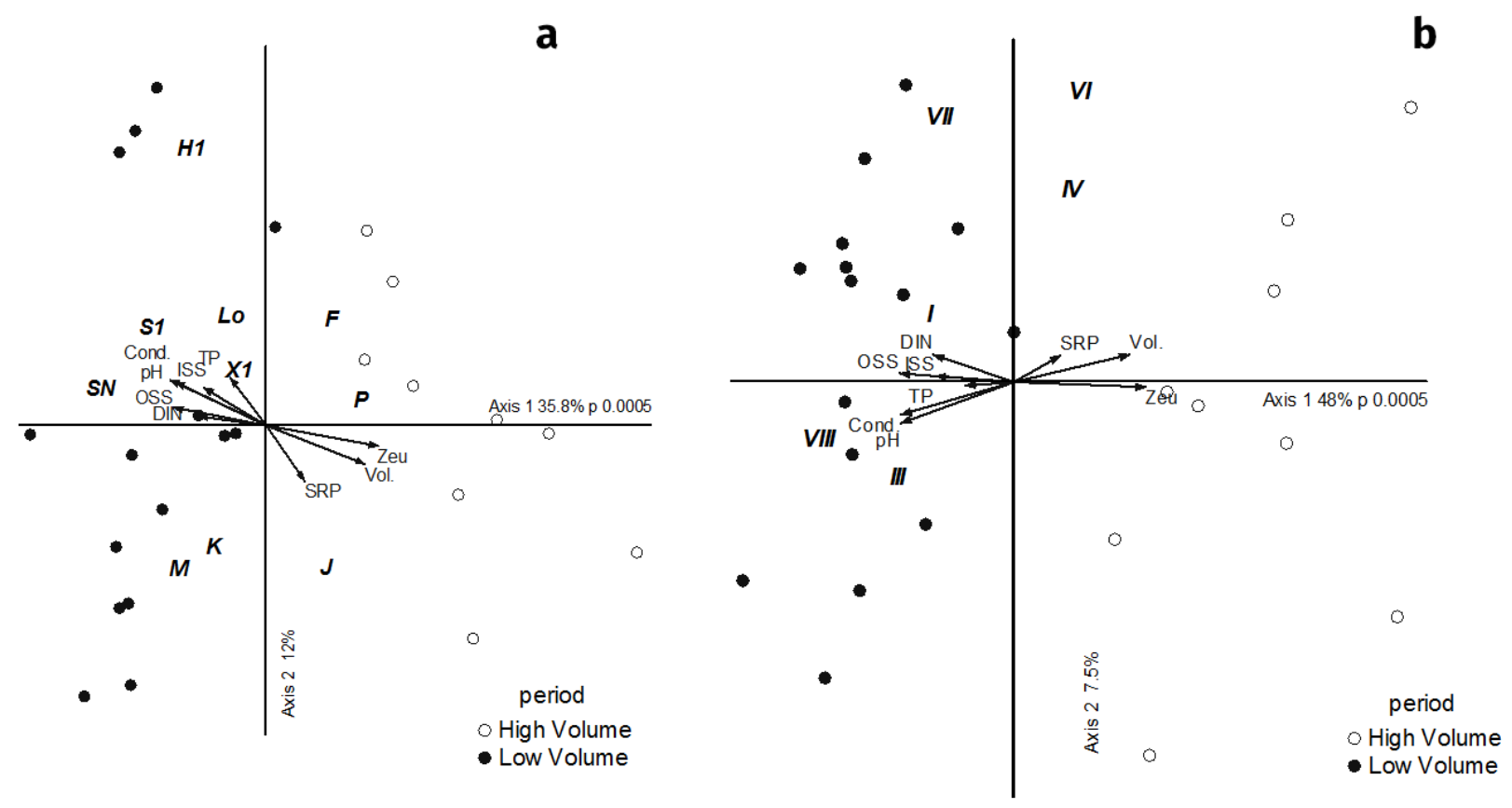

Figure 6. Redundancy analysis diagrams using Reynolds's Functional Groups (RFG) approach (a) and MorphologyBased Funcional Groups (MBFG) approach (b) with limnological variables (arrows) and monthly samplings (dots). Cond. = Conductivity; DIN = Dissolved Inorganic Nitrogen; ISS = Inorganic Suspended Solids; OSS = Organic Suspended Solids; $S R P=$ Soluble Reactive Phosphorus; TP = Total Phosphorus; Vol. $=$ Water volume; $z_{\text {eu }}=$ Euphotic depth.

Considering the RDA performed with the RFG classification, it is possible to observe a noticeable difference between samples from high volume and low volume periods. The functional groups related to higher transparency $\left(z_{\text {eu }}\right)$ values and water volume were $\mathbf{P}, \mathbf{J}$, and $\mathbf{F}$. Group $\mathbf{F}$ is composed of algae from clear water environments that are tolerant to nutrient deficiency and sensitive to high turbidity. Group J is commonly associated with shallow, mixed, highly enriched systems. Group P predominates in eutrophic and mixed water and tolerates medium light availability conditions (Reynolds et al. 2002, Padisák et al. 2009). On the other hand, samples from low volume periods were related to high turbidity and nutrient concentration (DIN and TP). Functional groups related to organic and inorganic turbidity were $\mathbf{S}_{\mathbf{N}}$ and $\mathbf{S}_{\boldsymbol{1}}$. Both groups are composed of filamentous cyanobacteria that tolerate light shortage in mixed environments, though $\mathbf{S}_{\mathbf{N}}$ predominates in warmer conditions. Despite a significant contribution to biomass during the low volume periods, group $\mathbf{M}$ did not show any strong relationship with selected variables, but it is known that this group predominates in low latitudes, shallow, and eutrophic to hypereutrophic lakes and also includes bloomforming cyanobacteria (Reynolds 2006).

The classification based just on morphological traits proposed by Kruket al. (2010) and also by Reynolds et al. (2014) demonstrated a slightly greater percentage of variance (0.5\%) compared with the RFG approach, but this is because the total variation in the data set decreases with a lower number of groups. Thus in this case both approaches can be considered equivalent, differing from the usual results 


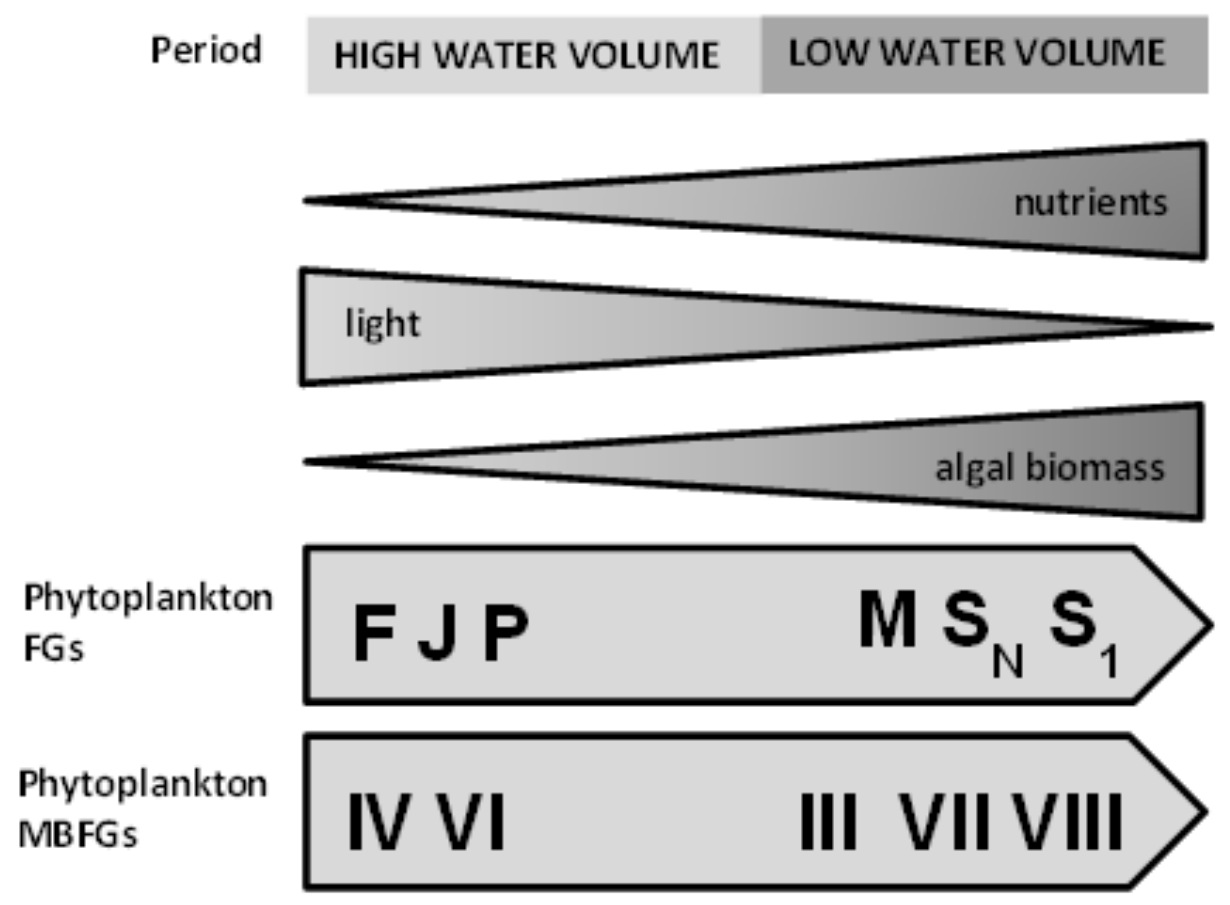

of other studies in which the MBFG approach demonstrated a more significant difference in variance compared with the RFG approach (Izaguirre et al. 2012, Hu et al. 2013, Rangel et al. 2016). The MBFG approach also showed a clear separation between high and low volume period samples. One of the advantages of this approach is the objectivity and independence from taxonomic affiliations that simplifies the classification process. It is important to note that using the RFG classification is necessary for a deeper knowledge of phytoplankton taxonomy and functional aspects.

The more representative MBFGs during the high volume periods were IV (organisms of medium size lacking specialized traits) and VI (non-flagellated organisms with siliceous exoskeletons), which were associated with less turbidity and meso-eutrophic conditions, while groups III (large gas-vacuolate filaments), VIII (nitrogen-fixing cyanobacteria), and I (small organisms with high S/V) were associated with DIN and turbidity. Group VII (large mucilaginous colonies) did not show a clear association with variables, although it is known that this group succeeds in eutrophic conditions (Kruk \& Segura 2012). It is important to mention that groups III and VIII were plotted next to each other, indicating that in this case nitrogen-fixing and non-fixing filaments do not show a significant difference in their responses to environmental conditions as proposed by Reynolds et al. (2014). This fact must be explained by the high availability of DIN during the low volume period, which contributed to reduced nitrogen competition between nitrogen-fixing and nonfixing cyanobacteria, allowing the co-dominance of these two MBFGs.

It is also important to remark that groups M and VII (both mostly represented by mucilaginous colonies) contributed a significant biomass during low volume period, but no clear association between environmental variables and these two groups was found. In this respect, Dantas et al. (2011) demonstrated that Microcystis aeruginosa, colonial cyanobacteria from groups 
$\mathbf{M}$ and $\mathbf{V I I}$, can co-dominate with $\mathbf{C}$. raciborskii in non-stratified eutrophic reservoirs such as the semi-arid Brazilian Lake Dourado. Thus the absence of stratification can also be considered an important environmental condition for the establishment of RFG $\mathbf{M}$ and MBFG VII.

Although studies on phytoplankton functional classification in Brazilian semi-arid lakes are scarce, the occurrence of groups $\mathbf{S}_{\mathbf{N}}$ and $\mathbf{V I I I}$ represented by Cylindrospermopsis raciborskii is frequently related to this region, particularly during drought periods and warmer conditions (Bouvy et al. 1999, 2000, Soares et al. 2013, Moura et al. 2018). This study also corroborates the predictions regarding climate change scenarios; that is, in shallow lakes during extended droughts, the dominance of bloomforming cyanobacteria will tend to become more frequent in the future (Intergovernmental Panel on Climate Change [IPCC] 2007, Marengo et al. 2010, Moss et al. 2011). All abundant groups during the low volume periods (RFG: $\mathbf{S}_{\mathbf{N}}$ and $\mathbf{M}$; MBFG: III, VII, and VIII) have bloom-forming cyanobacteria representatives, indicating a potential risk for water consumption and biodiversity (Borics et al. 2012).

Both classifications used separate samples from the low volume and high volume periods, and also demonstrated the importance of light availability on phytoplankton assemblage, as these two periods showed significant differences in their transparency and phytoplankton composition. Other studies comparing functional classifications reported good ecological predictions using RFG and MBFG classifications (Izaguirre et al. 2012, Hu et al. 2013, Rangel et al. 2016). It is reasonable to conclude that during extended droughts water volume reduction enhances the development of bloom-forming cyanobacteria groups through light limitation. Regarding the functional traits approaches, both demonstrated the effect of light availability on phytoplankton assemblage composition and can be applied in similar systems (Fig. 7). However, the functional approach proposed by Reynolds et al. (2002) provides more information and allows a more detailed description of the algal assemblages.

\section{Acknowledgments}

The authors are thankful to Conselho Nacional de Desenvolvimento Científico e Tecnológico (CNPq) and Financiadora de Estudos e Projetos (FINEP) Process No. 52009 for financial support. This research was financed in part by the Coordenação de Aperfeiçoamento de Pessoal de Nivel Superior - Brazil (CAPES) - Finance Code 001. We also thank Dr. Arthur Mattos in memoriam, coordinator of the project. We are thankful for the field and technical support team: Anderson Felipe de Medeiros Bezerra, José Neuciano P. de Oliveira, Jurandir Mendonça Junior, Maria Gabriela Bezerra, Maria da Conceição de Souza and Laíssa M. Torres. Special acknowledgments to Dr. Judit Padisák for suggestions to improve the manuscript.

\section{REFERENCES}

ALVARES CA, STAPE JL, SENTELHAS PC, GONÇALVES JLM \& SPAROVEK G. 2014. Köppen's climate classification map for Brazil. Meteorol Z 22: 711-728.

APHA - AMERICAN PUBLIC HEALTH ASSOCIATION. 2012. Standard Methods for the Examination of Water and Wastewater. $22^{\text {th }}$ ed., New York.

ARFI R. 2003. The effects of climate and hydrology on the trophic status of Sélingué reservoir, Mali, West Africa. Lakes Reserv Res Manag 8: 247-257.

BARBOSA JE, MEDEIROS ESF, BRASIL J, CORDEIRO RS, CRISPIM MCB \& SILVA GHG. 2012. Aquatic systems in semi-arid Brazil: limnology and management. Acta Limnol Bras 24: 103-118.

BARBOSA LG, BARBOSA PMM \& BARBOSA FAR. 2011. Vertical distribution of phytoplankton functional groups in a tropical shallow lake: driving forces on a dial scale. Acta Limnol Bras 23: 63-73.

BECKER V, HUSZAR VLM \& CROSSETTI LO. 2009. Responses of phytoplankton functional groups to the mixing regime in a deep subtropical reservoir. Hydrobiologia 628: 137-151.

BORICS G, TÓTHMÉRÉSZ B, LUKÁCS BA \& VÁRBÍRÓ G. 2012. Functional groups of phytoplankton shaping diversity of shallow lake ecosystems. Hydrobiologia 698: 251-262. 
BOUVY M, FALCÃO D, MARINHO M, PAGANO M \& MOURA A. 2000. Occurrence of Cylindrospermopsis (Cyanobacteria) in 39 Brazilian tropical reservoirs during the 1998 drought. Aquat Microb Ecol 23: 13-27.

BOUVY M, MOLICA R, OLIVEIRA S, MARINHO M \& BEKER B. 1999. Dynamics of a toxic cyanobacterial Bloom (Cylindrospermopsis raciborskii) in a shallow reservoirs in the semi-arid region of northeast Brazil. Aquat Microb Ecol 20: 285-297.

BOUVY M, NASCIMENTO SM, MOLICA RJR, FERREIRA A, HUSZAR V \& AZEVEDO SMFO. 2003. Limnological features in Tapacurá reservoir (northeast Brazil) during a severe drought. Hydrobiologia 493: 115-130.

BRASIL J, ATTAYDE JL, VASCONCELOS FR, DANTAS DDF \& HUSZAR VLM. 2016. Drought-induced water-level reduction favors cyanobacteria blooms in tropical shallow lakes. Hydrobiologia 770: 145-164.

BUCAK T, SARAOGLU E, LEVI EE, NIHAN TAVSANOGLU Ü, IDIL ÇAKIROGLU A, JEPPESEN E \& BEKLIOGLU M. 2012. The influence of water level on macrophyte growth and trophic interactions in eutrophic Mediterranean shallow lakes: a mesocosm experiment with and without fish. Freshw Biol 57: 1631-1642.

COLE GA. 1994. Textbook of Limnology. Waveland Press Inc, Illinois.

COOPS H, BEKLIOGLU M \& CRISMAN TL. 2003. The role of water-level fluctuations in shallow lake ecosystems workshop conclusions. Hydrobiologia 506: 23-27.

COSTA MRA, ATTAYDE JL \& BECKER V. 2016. Effects of water level reduction in the dynamics of phytoplankton functional groups in tropical semi-arid lakes. Hydrobiologia 778 : 75-89.

CROSSETTI LO, BECKER V, CARDOSO LS, RODRIGUES LR, COSTA LS \& MOTTA-MARQUES D. 2013. Is phytoplankton functional classification a suitable tool to investigate spatial heterogeneity in a subtropical shallow lake? Limnologica 43: 157-163.

DANTAS ÊW, MOURA NA \& BITTENCOURT-OLIVEIRA MC. 2011. Cyanobacterial blooms in stratified and destratified eutrophic reservoirs in semi-arid region of Brazil. An Acad Bras Cienc 83: 1327-1338.

DANTAS ÊW, BITTENCOURT-OLIVEIRA MC \& MOURA AN. 2012. Dynamics of phytoplankton associations in three reservoirs in northeastern Brazil assessed using Reynolds' theory. Limnologica 42: 72-80.

FIGUEIREDO A \& BECKER V. 2018. Influence of extreme hydrological events in the quality of water reservoirs in the semi-arid tropical region. Rev Bras Recur Hidricos 23: e53.

GERALDES AM \& BOAVIDA MJ. 2005. Seasonal water level fluctuations: Implications for reservoir limnology and management. Lakes Reser Res Manag 10: 59-69.

GUTTMAN NB. 1999. Accepting the standardized precipitation index: a calculation algorithm. J Am Water Resour Assoc 35: 311-322.

HARRIS GP \& BAXTER G. 1996. Interannual variability in phytoplankton biomass and species composition in a subtropical reservoir. Freshw Biol 35: 545-560.

HILLEBRAND H, DÜRSELEN CD, KIRSCHTEL DB, POLLINGHER U \& ZOHARY T. 1999. Biovolume calculation for pelagic and benthic microalgae. J Phycol 35: 403-424.

HU R, HAN B \& NASELLI-FLORES L. 2013. Comparing biological classifications of freshwater phytoplankton: a case study from South China. Hydrobiologia 701: 219-233.

HUSZAR VLM, SILVA LHS, MARINHO M, DOMINGOS P \& ANNA CLS. 2000. Cyanoprokaryote assemblages in eight productive tropical Brazilian waters. Hydrobiologia 424: 67-77.

IPCC - INTERgOVERNMENTAL PANEL ON CLIMATE CHANGE. 2007. Climate change 2007: impacts, adaptation and vulnerability. Contribution of working group II to the fourth assessment report of the intergovernmental panel on climate change. Parry ML, Canziani OF, Paulitikof JP, Van Der Linden PJ and Hanson CE (Eds), Cambridge University Press, Cambridge.

IZAGUIRRE I, ALLENDE L, ESCARAY R, BUSTINGORRY J, PÉREZ $G$ \& TELL G, 2012. Comparison of morpho-functional phytoplankton classifications in human-impacted shallow lakes with different stable states. Hydrobiologia 698: 203-216.

JAIN VK, PANDEY RP, JAIN MK \& BYUN H-R. 2015. Comparison of drought indices for appraisal of drought characteristics in the Ken River Basin. Weather and Climate Extremes 8: 1-11.

JATI S, BORTOLINI JC \& TRAIN S. 2017. Mixotrophic species influencing phytoplankton community structuring during the filling phase of a subtropical reservoir. Braz J Biol 40: 933-941.

JENSEN P, JEPPESEN E, OLRIK K \& KRISTENSEN P. 1994. Impact of nutrients and physical factors on the shift from cyanobacterial to chlorophyte dominance in shallow Danish lakes. Can J Fish Aquat Sci 51: 97-109.

JEPPESEN E ET AL. 2015. Ecological impacts of global warming and water abstraction on lakes and reservoirs 
due to changes in water level and related changes in salinity. Hydrobiologia 750: 201-227.

JESPERSEN AM \& CHRISTOFFERSEN K. 1988. Measurements of chlorophyll-a from phytoplankton using ethanol as extraction solvent. Hydrobiologia 109: 445-454.

KANGUR K, MÖLS T, MILIUS A \& LAUGASTE R. 2003. Phytoplankton response to changed nutrient level in Lake Peipsi in 1992-2001. Hydrobiologia 506: 265-272.

KRUK C., DEVERCELLI M., HUSZAR VLM, HERNÁNDEZ E, BEAMUD G, DIAZ M, SILVA LHS \& SEGURA AM. 2017. Classification of Reynolds phytoplankton functional groups using individual traits and machine learning techniques. Freshw Biol 62: 1681-1692.

KRUK C, HUSZAR VLM, PEETERS ETHM, BONILLA S, COSTA L, LÜRLING M, REYNOLDS CS \& SCHEFFER M. 2010. A morphological classification capturing functional variation in phytoplankton. Freshw Biol 55: 614-627.

KRUK C, MAZZEO N, LACEROT G \& REYNOLDS CS. 2002. Classification schemes for phytoplankton: a local validation of a functional approach to the analysis of species temporal replacement. J Plankton Res 24: 901-912.

KRUK C, PEETERS ETHM, VAN NES EH, HUSZAR VLM, COSTA LS \& SCHEFFER M. 2011. Phytoplankton community composition can be predicted best in terms of morphological groups. Limnol Oceanogr 56: 110-118.

KRUK C \& SEGURA AM. 2012. The habitat template of phytoplankton morphology-based functional groups. Hydrobiologia 698: 191-202.

LEIRA M \& CANTONATI M. 2008. Effects of water-level fluctuations on lakes: an annotated bibliography. Hydrobiologia 613: 171-184.

LITCHMAN E \& KLAUSMEIER CA. 2008. Trait-Based Community Ecology of Phytoplankton. Annu Rev Ecol Evol Syst 39: 615-639.

LITCHMAN E, PINTO PD, KLAUSMEIER CA, THOMAS MK \& YOSHIYAMA K. 2010. Linking traits to species diversity and community structure in phytoplankton. Hydrobiologia 653: $15-28$.

LUND JWG, KIPLING C \& LECREN ED. 1958. The inverted microscope method of estimationg algal number and the statistical basis of estimating by counting. Hydrobiologia 11: 143-170.

MANTZOUKI E, VISSER PM, BORMANS M \& IBELINGS BW. 2016. Understanding the key ecological traits of cyanobacteria as a basis for their management and control in changing lakes. Aquat Ecol 50: 333-350.
MARENGO JA, AMBRIZZI T, ROCHA RP, ALVES LM, CUANDRA SV, VALVERDE MC, TORRES RR, SANTOS DC \& FERRAZ SET. 2010. Future change of climate in South America in the late twenty-first century: intercomparison of scenarios from three regional climate models. Clim Dyn 35: 1089-1113.

MCCUNE B \& MEFFORD MJ. 2011. PC-ORD. Multivariate Analysis of Ecological Data, Version 4.MjM Software Design, Gleneden Beach.

MCKEE TB, DOESKEN NJ \& KLEIST J. 1995. Drought monitoring with multiple time scales. Proceedings of the Ninth Conference on Applied Climatology; p. 233-236. American Meteorological Society, Boston.

MEDEIROS LC, MATTOS A, LÜRLING M \& BECKER V. 2015. Is the future blue-green or brown? The effects of extreme events on phytoplankton dynamics in a semi-arid manmade lake. Aquat Ecol 49: 293-307.

MISHRA KA \& SINGH VP. 2010. A review of drought concepts. J Hidrol 391: 202-216.

MOURA AN, ARAGÃO-TAVARES NKC \& AMORIM CA. 2018. Cyanobacterial blooms in freshwater bodies from a semiarid region, Northeast Brazil: A review. J Limnol 77: 179-188.

MOSS B ET AL. 2001. Allied attack: climate change and eutrophication Inland Waters. Inland Waters 1: 101-105.

MURPHY J \& RILEY JP. 1962. A modified single solution method for the determination of phosphate in natural waters. Anal Chim Acta 27: 31-36.

NASELLI-FLORES L. 2000. Phytoplankton assemblages in twenty-one Sicilian reservoirs: relationships between species composition and environmental factors. Hydrobiologia 424: 1-11.

NASELLI-FLORES L. 2003. Man-made lakes in Mediterranean semi-arid climate: the strange case of Dr Deep Lake and Mr Shallow Lake. Hydrobiologia 506: 13-21.

NASELLI-FLORES L \& BARONE R. 2005. Water-Level Fluctuations in Mediterranean Reservoirs: Setting a Dewatering Threshold as a Management Tool to Improve Water Quality. Hydrobiologia 548: 85-99.

PADISÁK J, BORICS G, GRIGORSZKY I \& SORÓCZKY-PINTÉR É. 2006. Use of phytoplankton assemblages for monitoring ecological status of lakes within the Water Framework Directive: the assemblage index. Hydrobiologia. 553: 1-14.

PADISÁK J, CROSSETTI LO \& NASELLI-FLORES L. 2009. Use and misuse in the application of the phytoplankton functional classification: a critical review with updates. Hydrobiologia 621: 1-19. 
RANGEL LM, SOARES MCS, PAIVA R \& SILVA LHS. 2016. Morphology-based functional groups as effective indicators of phytoplankton dynamics in a tropical cyanobacteria-dominated transitional river-reservoir system. Ecol Indic 64: 217-227.

REYNOLDS CS. 1990. Temporal scales of variability in pelagic environments and the response of phytoplankton. Freshw Biol 23: 25-53.

REYNOLDS CS. 1998. What factors Influence the species composition of phytoplankton in lakes of different trophic status? Hydrobiologia 369-370: 11-26.

REYNOLDS CS. 2006. The Ecology of Freshwater Phytoplankton. Cambridge University Press, Cambridge.

REYNOLDS CS, ELLIOTT JA \& FRASSL MA. 2014. Predictive utility of trait-separated phytoplankton groups: A robust approach to modeling dynamics. J Great Lakes Res 40: 143-150.

REYNOLDS CS, HUSZAR V, KRUK C, NASELLI-FLORES L \& MELO S. 2002. Towards a functional classification of the freshwater phytoplankton. J Plankton Res 24: 417-428.

SCHEFFER M \& JEPPESEN E. 2007. Regime shifts in shallow lakes. Ecosystems 10: 1-3.

SELMECZY GB, ABONYI A, KRIENITZ P, KASPRZAK P, CASPER P, TELCS A, SOMOGYVÁRI Z \& PADISÁK J. 2019. Old sins have long shadows: climate change weakens efficiency of trophic coupling of phyto- and zooplankton in a deep oligo-mesotrophic lowland lake (Stechlin, Germany) - a causality analysis. Hydrobiologia 831: 101-117.

SHANNON CE \& WEAVER W. 1963. The mathematical theory of communication. Urbana: Illinios University Press, Illinios.

SILVA N, SANTOS JPO, OLIVEIRA DL, SILVA JS, SILVA KDP, DANTAS EW \& BARBOSA LG. 2018. Spatial and temporal dynamics of functional groups of phytoplankton in a tropical shallow lake. Acta Limnol Bras 30: e102.

SMITH PT. 1996. Light and nutrients effects on the relative biomass of blue-green algae in lake phytoplankton Can J Fish Aquat Sci 43: 148-153.

SOARES MCS, HUSZAR VLM, MIRANDA MN, MELLO MM, ROLAND F \& LÜRLING M. 2013. Cyanobacterial dominance in Brazil: distribution and environmental preferences. Hydrobiologia 717: 1-12.

SOMMER U, PADISÁK J, REYNOLDS CS \& JUHASZ-NAGY P. 1993. Hutchinson's heritage: the diversity-disturbance relationship in phytoplankton. Hydrobiologia 249: 1-7.

SOUZA DG, BUENO NC, BORTOLINI JC, RODRIGUES LC, BOVOSCOMPARIN VM \& FRANCO GMS. 2016. Phytoplankton functional groups in a subtropical Brazilian reservoir: responses to impoundment. Hydrobiologia 779: 47-57.

TEREFI M ET AL. 2014. Strong effects of occasional drying on subsequent water clarity and cyanobacterial blooms in cool tropical reservois. Freshw Biol 59: 870-884.

THORNTON JA \& RAST W. 1993. A test of hypotheses relating to the comparative limnology and assessment of eutrophication in semi-arido man-made lakes. In: STRASKRABA ML ET AL. (Eds), Comparative Reservoir Limnology and Water Quality Management, Netherlands: Springer Netherlands, p. 1-24.

TORREMORELL A, BUSTINGORRY J, ESCARAY R \& ZAGARESE H. 2007. Seasonal dynamics of a large, shallow lake, laguna Chascomu's: the role of light limitation and other physical variables. Limnologica 37: 100-108.

TUNDISI JG. 1990. Distribuição espacial, sequência temporal e ciclo sazonal do fitoplâncton em Represas: Fatores Limitantes e Controladores. Rev Bras Biol 50: 937-955.

UHELINGER V. 1964. Étude statistique dês méthodes de dénobrement planctonique. Arch Sci 17: 121-123.

UTERMÖHL H. 1958. Zur vervollkommung der quantitativen phytoplankton - methodik. Mitt Int Verein Limnol 9: 1-38.

VALDERRAMA JC. 1981. The simultaneous analysis of total and phosphorus in natural waters. Mar Chem 10: 109-122.

WETZEL ZG \& LIKENS GE. 2000. Limnological analyses, $3^{\text {rd }}$ ed., Springer, New York.

YANG J, LV H, YANG J, LIU L, YU X \& CHEN H. 2016. Decline in water level boosts cyanobacteria dominance in subtropical reservoirs. Sci Total Environ 557-558: 445-452.

\section{How to cite}

BRAGA GG \& BECKER V. 2020. Influence of water volume reduction on the phytoplankton dynamics in a semi-Arid Man-made lake: A comparison of two morphofunctional approaches. An Acad Bras Cienc 91: e20181102. DOI 10.1590/0001-3765202020181102.

Manuscript received on October 22, 2018; accepted for publication on August 30, 2019

\section{GUSTAVO G. BRAGA ${ }^{1}$}

https://orcid.org/0000-0002-3395-4148

\section{VANESSA BECKER ${ }^{1,2}$}

https://orcid.org/0000-0002-7326-4328 
${ }^{1}$ Programa de Pós-Graduação em Ecologia,

Universidade Federal do Rio Grande do Norte, Av.

Salgado Filho, 3000, 59078-970 Natal, RN, Brazil

${ }^{2}$ Departamento de Engenharia Civil, Universidade

Federal do Rio Grande do Norte, Av. Salgado

Filho, 3000, 59078-970 Natal, RN, Brazil.

Correspondence to: Vanessa Becker

E-mail:becker.vs@gmail.com

\section{Author contributions}

Each author contributed individually and significantly for the development of the study. GGB and VB developed the theoretical framework and took the lead in writing the manuscript. GGB contributed to samples preparation and made the phytoplankton quantification and biomass calculation. GGB and VB contributed to the interpretation of the results. VB was involved in planning and supervised the work.

\section{(cc) BY}

